\title{
The Lawless Execution of Robert Alton Harris
}

\author{
Evan Caminker ${ }^{\dagger}$ and Erwin Chemerinsky ${ }^{\dagger \dagger}$
}

\section{INTRODUCTION}

Robert Alton Harris died in the gas chamber of California's San Quentin prison early Tuesday morning, April 21, 1992. Harris, the first person executed in California since 1967, ${ }^{1}$ had been convicted for committing two murders.

The few days before Harris' death contained a flurry of legal activity. On Friday, April 17-about eighty hours before the scheduled execution-attorneys representing death row inmates in California filed a class action lawsuit in the Northern District of California to have the use of the gas chamber declared cruel and unusual punishment in violation of the Eighth Amendment to the United States Constitution. ${ }^{2}$ The suit sought a temporary restraining order barring Harris' execution. ${ }^{3}$

Over an Easter and Passover weekend, attorneys frantically litigated the issue before the district court, the United States Court of Appeals for the Ninth Circuit, and the United States Supreme Court. Although the district court issued a temporary restraining order preventing the execution for ten days, ${ }^{4}$ an appellate court panel vacated the order and allowed the execution to go forward as scheduled. ${ }^{5}$ Judges of the Ninth Circuit issued four additional stays, each overturned by the Supreme Court.

The judicial opinions entered over these few days are shocking. The majority of the Ninth Circuit panel that overturned the district court's temporary restraining order, and the seven Supreme Court Justices who vacated the subsequent stays of execution, ignored or misapplied legal principles without justifying their departures from established law. Their understandable frustration

$\dagger$ Acting Professor of Law, University of California at Los Angeles School of Law.

t† Legion Lex Professor of Law, University of Southern California Law Center. We want to thank the following people for their excellent comments and suggestions: Akhil Reed Amar, Vik Amar, Kendall Goh, Carole Goldberg-Ambrose, Robert Goldstein, Alan Hirsch, Ed Lazarus, Malcolm Stewart, Jonathan Varat, and Chuck Weisselberg.

1. Aaron Mitchell was executed on April 12, 1967. See Kevin Leary, Eyewitness Account, S.F. CHRON., Apr. 22, 1992, at A1.

2. Fierro v. Gomez, 790 F. Supp. 966 (N.D. Cal. 1992).

3. The suit also sought a declaratory judgment that death in the gas chamber is cruel and unusual punishment and a permanent injunction against such executions.

4. Fierro, 790 F. Supp. at 966.

5. Gomez v. United States Dist. Court, No. 92-70237, 1992 U.S. App. LEXIS 7931 (9th Cir. Apr. 20, 1992), vacated as moot and withdrawn, 1992 U.S. App. LEXIS 10088 (9th Cir. May 5, 1992), modifying 1992 U.S. App. LEXIS 8857 (9th Cir. Apr. 22, 1992). 
resulting from recent experiences with delayed executions led to a last-minute rush to execution in this case. To ensure that the State executed Harris as scheduled, judges sworn to uphold the Constitution failed to exercise their responsibility to exercise detached, considered judgment.

For several reasons, we think it is important to describe in detail the ways in which some judges and Justices either ignored or misapplied the law in this case. ${ }^{6}$ First, exposing the legal errors may lessen the likelihood of their recurrence. Whether or not capital punishment is desirable and whether or not death in the gas chamber is cruel and unusual, courts should follow the law.

Second, this case ought to prompt a reexamination of the manner in which the legal system should handle capital cases. The legal events immediately preceding Harris' execution revealed two very different views about the death penalty. On the one hand, the district court judge and the Ninth Circuit judges who issued the stays believed that a person should not be executed when a potentially meritorious argument has been presented but not yet considered by a court. Under this view, preservation of the rule of law takes precedence over expediency of execution. On the other hand, the Ninth Circuit panel and the Supreme Court believed that too many delays had already been tolerated. Under this view, finality is more important than hearing every meritorious legal claim; there simply comes a point when legal proceedings must end and punishment must be imposed.

The former viewpoint is the only decent and humane approach to be taken if the United States continues to practice capital punishment: "It is . . . important that before we allow human lives to be snuffed out we be sure-emphatically sure-that we act within the law."7 Even those who disagree with this perspective should be troubled that the desire to facilitate speedy executions leads some courts to regard all last-minute appeals as manipulative and frivolous. A knee-jerk tendency to dismiss all petitions filed close to execution dates could cause potentially meritorious claims to be ignored.

Finally, we write about what occurred because of what it reveals about the current Supreme Court. As much as any case yet decided, the Rehnquist Court's handling of the Harris execution lays bare its judicial character. Out of a desire to achieve a result-Harris' execution-the Court mischaracterized the issue, applied the wrong legal standard, and arrogated to itself a power of superintendence over all federal courts that it simply does not possess. As Justice Thurgood Marshall remarked at the end of his last term on the Court, "Power,

6. In this article, we do not discuss the merits of the claim that death in the gas chamber is cruel and unusual punishment. Nor do we discuss the merits of Robert Harris' conviction or death sentence. See Charles M. Sevilla \& Michael Laurence, Some Comments on the Causes of Discontent with the Death Penalty: The Case of Robert Harris, 40 UCLA L. REv. (1992) (forthcoming Dec. 1992). For an excellent discussion and critique of the law's criteria for attributing moral culpability sufficient to justify convicting and sentencing someone to death, see Peter Arenella, Convicting the Morally Blameless: Reassessing the Relationship Between Legal and Moral Accountability, 39 UCLA L. REV. 1511 (1992).

7. Rosenberg v. United States, 346 U.S. 273, 321 (1953) (Douglas, J., dissenting). 
not reason, is the new currency of this Court's decisionmaking." It is tragic that this power means that people such as Robert Alton Harris will die without having their legal claims heard.

\section{WHAT HAPPENED?}

Robert Harris was scheduled to die on Tuesday, April 21, 1992. On Friday, April 17, three death row inmates (including Harris) filed a class action lawsuit, on behalf of themselves and others similarly situated, pursuant to 42 U.S.C. $\S 1983$, in which they alleged that executions in the gas chamber constitute cruel and unusual punishment in violation of the Eighth Amendment to the United States Constitution. The case was assigned to Judge Marilyn Hall Patel in the United States District Court for the Northern District of California. Following briefing and oral arguments on Saturday, April 18, Judge Patel issued a ten-day temporary restraining order halting Harris' execution. ${ }^{9}$

Judge Patel applied the well-established Ninth Circuit principle that a party who can "'show either (1) a likelihood of success on the merits and the possibility of irreparable injury, or (2) the existence of serious questions going to the merits and the balance of hardships tipping in [the petitioner's] favor" is entitled to a temporary restraining order. ${ }^{10}$ Judge Patel found that the plaintiffs satisfied the second prong of the test. In the section of the opinion entitled, "Serious Questions Going to the Merits," Judge Patel first noted that the Supreme Court has declared that "[ $t]$ he Eighth Amendment proscribes "punishments which are incompatible with the evolving standards of decency that mark the progress of a maturing society." 11 Punishment that "involves torture or a lingering death" or "the unnecessary and wanton infliction of pain" violates the Eighth Amendment. ${ }^{12}$

Regarding the cruelty of the gas chamber, Judge Patel determined:

the evidence submitted by plaintiffs suggests that lethal gas may be slow, painful and torturous in violation of the Eighth Amendment. In fact, the eyewitness descriptions of executions by lethal gas .... are comparable to the descriptions ... in ... a case in which the [Washington Supreme Court] found hanging to be an unconstitutional method of execution. ${ }^{13}$

\footnotetext{
8. Payne v. Tennessee, 111 S. Ct. 2597, 2619 (1991) (Marshall, J., dissenting).

9. Fierro v. Gomez, 790 F. Supp. 966, 971 (N.D. Cal. 1992).

10. Id. at 970 (quoting Oakland Tribune, Inc. v. Chronicle Publishing Co., 762 F.2d 1374, 1376 (9th Cir. 1985)).

11. Id. (quoting Estelle v. Gamble, 429 U.S. 97, 102 (1976)).

12. Id. at $970-71$.

13. Id. at 971; see State v. Frampton, 627 P.2d 922, 934-35 (Wash. 1981).
} 
Regarding whether a punishment is unusual as well as cruel, the Supreme Court has emphasized that "[ $t]$ he clearest and most reliable evidence of contemporary values is the legislation enacted by the country's legislatures."14 Judge Patel concluded that the other states' practices indicate that an execution by gas is very unusual and arguably violative of evolving standards of decency. For example, the gas chamber is used for executions in only three of thirty-eight United States jurisdictions with the death penalty. ${ }^{15}$ Of these three states, only Arizona has performed an execution within the last twenty-five years. Furthermore, in the last fifteen years, eight states have abandoned the use of the gas chamber as a means of execution. ${ }^{16}$

Second, Judge Patel found that the balance of hardships justified imposing the stay. Granting the temporary restraining order would mean inconveniencing the State by delaying the execution, but Judge Patel explained that "[t]he inconvenience to the state is inconsequential compared to the certainty that plaintiff Harris' impending execution would go forward without review of his constitutional claims."

After rejecting the State's procedural objections to the issuance of a temporary restraining order, ${ }^{18}$ Judge Patel granted a ten-day delay in the execution to permit consideration of the merits of the plaintiffs' arguments. ${ }^{19}$ She entered her order on Saturday night, April 18. The State of California immediately filed a petition in the United States Court of Appeals for the Ninth Circuit seeking an emergency writ of mandate vacating the district court's temporary restraining order.

A divided panel of Ninth Circuit judges issued the requested writ of mandate. ${ }^{20}$ Judge Alarcon, joined by Judge Brunetti, constituted the majority; Judge Noonan dissented. The majority opinion concluded that "the district court lacked the jurisdiction to enjoin the execution of the state court's judgment under the principles of federalism and comity first announced in Younger $v$. Harris."21 Relying entirely on the Younger abstention doctrine, the court

14. Penry v. Lynaugh, 492 U.S. 302, 331 (1989), quoted in, Fierro, 790 F. Supp. at 971.

15. Fierro, 790 F. Supp. at 971 . These states are California, Arizona, and Maryland. Id.

16. Id.

17. Id.

18. The State raised two basic procedural objections: (1) the case properly should have been considered as a habeas corpus petition; and (2) abstention was appropriate under Younger v. Harris, 401 U.S. 37 (1971). Each of these issues is discussed infra notes 35-65 and accompanying text.

19. In reality under Califomia law, the delay would have been a bit longer because a new execution date would have needed to be set. This likely would have meant a thirty to sixty day delay before the execution. See Stephen Reinhardt, The Supreme Court, the Death Penalty and the Harris Case, 102 YALE L.J. 205, 222 (1992).

20. Gomez v. United States Dist. Court, No. 92-70237, 1992 U.S. App. LEXIS 7931 (9th Cir. Apr. 20, 1992), vacated as moot and withdrawn, 1992 U.S. App. LEXIS 10088 (9th Cir. May 5, 1992), modifying 1992 U.S. App. LEXIS 8857 (9th Cir. Apr. 22, 1992).

21. Id. at *3. 
granted the writ of mandamus and ordered the district court to vacate the temporary restraining order. ${ }^{22}$

For reasons discussed in detail below, the panel's treatment of the gas chamber claim was sufficiently troubling that various Ninth Circuit judges called for en banc reconsideration of the decision. However, the manner in which the panel issued its decision contributed significantly to the harried nature of the subsequent Ninth Circuit deliberations. The panel announced its decision and issued the order granting the State's petition for writ of mandate at about 11:00 p.m. p.d.t. on Sunday, April 19 and transmitted the writ by fax to the district court at 11:23 a.m. on Monday. But the panel did not circulate an opinion setting forth the reasoning underlying its action until sixteen hours after issuing the order, at approximately 3:00 p.m. on Monday. ${ }^{23}$ This allowed the rest of the Ninth Circuit only nine hours after the opinion was circulated to evaluate the need for and to vote for en banc reconsideration before the scheduled execution. ${ }^{24}$

At some point Monday evening, a group of ten Ninth Circuit judges entered an order staying the execution in an attempt to secure enough time for the whole court to decide whether to grant en banc review. ${ }^{25}$ Simultaneously, another judge led an effort to convince the panel to recall its mandate to reinstate the district court's temporary restraining order pending en banc review. This effort failed but generated an additional stay. ${ }^{26}$

As this chronology demonstrates, the late evening stays were largely a wellintentioned effort by several Ninth Circuit judges who sought to enable the court as a whole to decide whether en banc review was appropriate. Politicians and commentators criticized the late stays as last-ditch efforts by liberal judges to thwart the execution without justification. Governor Pete Wilson, for example, characterized the evening's events as a "macabre legal circus" performed by "manipulative lawyers and indulgent judges." 27 This characterization is unfair: the stays were timely and considered responses to the patently weak

22. There was also a collateral set of proceedings, including a stay issued by a Ninth Circuit judge. This stay involved a federal habeas corpus petition alleging that newly discovered evidence about Harris' brother's involvement in the killings ought to diminish Harris' culpability for the offense. Harris v. Vasquez, 961 F.2d 1450 (9th Cir. 1992). Early Monday evening, the Supreme Court vacated this stay. Vasquez v. Harris, 112 S. Ct. 1713 (1992) (No. 4); see Reinhardt, supra note 19, at 209-10 (discussing first stay). We do not evaluate this collateral set of proceedings, which did not affect the events we discuss and does not bear on our thesis.

23. Gomez, 1992 U.S. App. LEXIS 7931, at *10 (Noonan, J., dissenting).

24. Further logistical difficulties compounded this time pressure: Ninth Circuit judges are scattered over the entire western part of the United States, and the court's electronic-mail system was overwhelmed by the volume of messages and suffered periodic failures throughout the night. Hence it was difficult for the judges to communicate quickly and effectively among themselves. See Reinhardt, supra note 19, at 209.

25. Gomez v. United States Dist. Court, No. 92-70237 (9th Cir. Apr. 20, 1992) (Hug, Fletcher, Pregerson, Poole, D.W. Nelson, Norris, Canby, Reinhardt, Noonan \& T.G. Nelson, J.J.) (second stay).

26. Gomez v. Vasquez, No. $92-55426$ (9th Cir. Apr. 20, 1992) (third stay).

27. George Skelton, Wilson Denounces 'Macabre Circus' of Execution, L.A. TIMES, Apr. 23, 1992, at $\mathrm{A36.}$ 
analysis offered by the panel for its decision to vacate the district court's temporary restraining order and thereby facilitate Harris' death. ${ }^{28}$

Late Monday night, in a terse per curiam opinion, the Supreme Court vacated these two stays. The Court did not affirm the Ninth Circuit panel's reasons for overturning Judge Patel's temporary restraining order. Rather, the Supreme Court treated the gas chamber claim as if it were brought pursuant to a habeas corpus petition and explained that, because Harris already had filed several habeas corpus petitions, this latest successive petition was improper under McClesky $v$. Zant. ${ }^{29}$ The Court further commented that regardless of whether Harris' suit was denominated a habeas corpus petition or a new civil suit, he could have brought the claim more than a decade ago. The Supreme Court concluded that "[t]here is no good reason for this abusive delay, which has been compounded by last-minute attempts to manipulate the judicial process. ${ }^{" 30}$

Justices Stevens and Blackmun filed a dissenting opinion. They evaluated the evidence and concluded that there was a substantial likelihood that a court reaching the merits would find death by gas chamber to be cruel and unusual. $^{31}$

The Supreme Court's decision vacating the stays was rendered in the earliest hours of Tuesday, April 21. At approximately 3:49 a.m. p.d.t., state officials led Harris to the gas chamber and strapped him into the seat. Literally seconds before the lethal gas was created in the chamber, Ninth Circuit Judge Harry Pregerson entered a final stay. ${ }^{32}$ Judge Pregerson reasoned that if Harris' suit was properly characterized as a habeas corpus petition, then Harris should have the opportunity to exhaust available state court remedies. No state court had yet ruled on his claim that death in the gas chamber was cruel and unusual.

Within two hours, the Supreme Court vacated Judge Pregerson's new stay. The Court also ordered: "No further stays of Robert Alton Harris' execution shall be entered by the federal courts except upon order of this Court."33

At about 6:00 a.m. p.d.t., officials again led Harris to the gas chamber and strapped him into the chair. Cyanide pellets were dropped into the sulfuric acid at about 6:10; at 6:21 Harris was pronounced dead..$^{34}$

28. Reinhardt, supra note 19 , at 209-14.

29. Gomez v. United States Dist. Court, 112 S. Ct. 1652, 1653 (1992).

30. Id.

31. Id. at 1653-56.

32. Harris v. Vasquez, No. $92-70237$ (9th Cir. Apr. 21, 1992) (Pregerson, J.) (fourth stay); see Harris' Last Appeals, S.F. CHRON., Apr. 22, 1992, at A8.

33. Vasquez v. Harris, 112 S. Ct. 1713, 1714 (1992) (No. 5). A1.

34. See Dan Morain \& Tom Gorman, Harris Dies Afier Judicial Duel, L.A. TMME, Apr. 22, 1992, at 


\section{THE COURTS' LEGAL ERRORS}

The Ninth Circuit panel opinion and the Supreme Court's opinions invite criticism in two respects. First, the courts articulated rationales for their rulings that ignored or misapplied legal principles without justifying departure from settled law. Second, the courts failed to take the time and care necessary to analyze the subtle legal issues actually posed by the case-none of which ultimately support the courts' rulings. We explore the courts' errors of both commission and omission below.

\section{A. The Court of Appeals Panel Decision}

The Ninth Circuit panel decision relied on the Younger v. Harris ${ }^{35}$ abstention doctrine as its sole basis for vacating Judge Patel's temporary restraining order. $^{36}$ In Younger, the Supreme Court reversed a federal district court's injunction halting state court proceedings as "a violation of the national policy forbidding federal courts to stay or enjoin pending state court proceedings except under special circumstances." ${ }^{37}$ The court asserted that the doctrine required dismissal of Harris' suit because his claim could have been presented earlier in state court. The court did not contend that Younger applied because federal court review would unduly interfere with a state proceeding then pending; rather, the court contended that Younger applied whether or not a state proceeding was ongoing. ${ }^{38}$ The court concluded:

Here, Harris has not given the California courts an opportunity to adjudicate his claim that the injection of lethal gas, in carrying out a sentence of death, violates the federal constitution. The district court was required to abstain. The district court clearly erred as a matter of law in granting a temporary restraining order in this matter. ${ }^{39}$

This is a dramatic extension of Younger v. Harris-an application truly without precedent. Under current Supreme Court case law, Younger abstention applies only where federal review would unduly interfere with a pending state court proceeding - a situation inapplicable to Harris. In Younger, the plaintiff had been indicted in state court and sought an injunction in federal court against the state prosecution. The Court concluded that when state court proceedings are pending in which the defendant has constitutional challenges available, the

\footnotetext{
35. 401 U.S. 37 (1971).

36. Gomez, 1992 U.S. App. LEXIS 7931 (9th Cir. Apr. 20, 1992).

37. 401 U.S. at 41.

38. Id. at $* * 5-6$.

39. Id. at **8-9.
} 
constitutional claims should be presented in state court and the federal court should not hear the case while the state adjudication takes place. ${ }^{40}$

The Younger Court explicitly confined its holding to cases in which state court proceedings are pending, such that federal court involvement would intrude upon the normal progress of the state court. The Court reaffirmed this conclusion in Steffel v. Thompson, ${ }^{41}$ which held that Younger did not bar a federal court injunction when no state court litigation was pending. As Justice Brennan explained: "When no state criminal proceeding is pending at the time the federal complaint is filed, federal intervention does not result in duplicative legal proceedings or disruption of the state criminal justice system. ${ }^{\$ 42}$

Since Steffel, the Court has consistently adhered to this characterization of the Younger abstention doctrine. The Supreme Court recently explained that "Younger v. Harris . . . imposes heightened requirements for an injunction to restrain an already-pending or an about-to-be-pending state criminal action, or civil action involving important state interests." 43 Indeed, in its most recent consideration of Younger abstention, in June 1992, the Supreme Court declared: "Absent any pending proceeding in state tribunals ... application ... of Younger abstention was clearly erroneous." 44

The Ninth Circuit panel nevertheless asserted that Younger required abstention merely because Harris had enjoyed previous opportunities to litigate the gas chamber claim in state court, whether or not federal review at that point would unduly intrude upon a pending state proceeding. The panel relied on the Supreme Court's decision in Huffman v. Pursue, Ltd. $^{45}$ as authority. ${ }^{46}$

The panel, however, misapplied Huffman and ignored a later decision that expressly limits Huffman's scope. In Huffman, state officials instituted a civil nuisance proceeding in state court against an adult movie theater for violating an Ohio statute declaring the exhibition of obscene films to be a nuisance. ${ }^{47}$ The State prevailed and obtained a judgment closing the theater for a year. Rather than appealing the judgment within the state system, the theater management sought injunctive and declaratory relief in federal court under 42 U.S.C. $\S 1983$.

The Supreme Court held that the district court should have abstained. Although the state trial court proceedings were completed, the Court nonetheless held that Younger precluded jurisdiction because abstention is appropriate until all of the state appellate proceedings are completed. Justice Rehnquist, writing for the Court, stated:

40. Id. at 54 .

41. 415 U.S. 452 (1974).

42. Id. at 462 .

43. Morales v. Trans World Airlines, 112 S. Ct. 2031, 2036 n.l (1992) (emphasis added).

44. Ankenbrandt v. Richards, 112 S. Ct. 2206, 2216 (1992).

45. 420 U.S. 592 (1975).

46. Gomez, 1992 U.S. App. LEXIS 7931, at **6-7.

47. 420 U.S. at $595-98$. 
Virtually all of the evils at which Younger is directed would inhere in federal intervention prior to completion of state appellate proceedings, just as surely as they would if such intervention occurred at or before trial. Intervention at the later stage is if anything more highly duplicative, since an entire trial has already taken place, and it is also a direct aspersion on the capabilities and good faith of state appellate courts. $^{48}$

The Huffman Court acknowledged that it did not know if there was still time for appeal in the state system, but concluded this did not matter because the "appellee may not avoid the standards of Younger by simply failing to comply with the procedures of perfecting its appeal within the Ohio judicial system." 49

The Supreme Court subsequently limited Huffman's scope in Wooley $v$. Maynard..$^{50}$ In Wooley, Maynard had thrice been convicted for violating a New Hampshire statute by covering up the state motto, "Live Free or Die," on his license plates. The defendant did not appeal any of the convictions but instead brought a federal suit to enjoin future prosecutions. The Court distinguished Huffman and found abstention inappropriate. Chief Justice Burger, writing for the majority, stated: "[T] he suit is in no way 'designed to annul the results of a state trial' since the relief sought is wholly prospective, to preclude further prosecution under a statute alleged to violate appellees' constitutional rights."

The Ninth Circuit panel's citation to Huffman thus does not support its abstention ruling: Wooley, not Huffman, is the controlling authority. Harris was seeking wholly prospective relief: an injunction to preclude execution in the gas chamber. In Huffman, the plaintiff sought to use $\S 1983$ as a form of appellate review of the state court proceeding; the plaintiff sought to have the federal court supersede a state court judgment. If the federal court plaintiff had succeeded in Huffiman, the state proceedings would have been-in the words of Wooley-"annulled." In Wooley, in contrast, the plaintiff sought a federal court order to prevent a future wrongful act: additional arrests for violating the state's license plate law. In Harris' federal class action suit, Harris did not seek to invalidate the state court's judgment that he was guilty of murder and would be executed. Rather, Harris sought to prevent a future wrongful act: his execution in the gas chamber.

In addition, if Huffman is read so broadly as to preclude Harris' federal court suit, the case would radically change the law and end virtually all federal litigation about state prison conditions. The Ninth Circuit panel stated that, because Harris could have challenged the manner of execution in state court

48. Id. at 608 .

49. Id. at 611 n.22.

50. 430 U.S. 705 (1977).

51. Id. at 711 (quoting Huffman, 420 U.S. at 609).

52. Id. 
proceedings, no federal suit raising this claim was permitted. ${ }^{53}$ By this reasoning, any person convicted in state court, who could challenge foreseeable adverse prison conditions at the time of sentencing, likewise could not later challenge those conditions in federal court. Such a bar would be improper for exactly the reason that Huffman did not apply to Harris' suit. Huffman precludes only federal court litigation that would annul the state court decision-in a criminal case, the conviction and sentence. Subsequent litigation about prison conditions or methods of execution does not annul the state court judgment. The Ninth Circuit panel's reliance on Huffman is therefore unfounded. ${ }^{54}$

Moreover, the panel's invocation of abstention based simply on Harris' prior opportunity to raise his gas chamber claim in state court contravenes a separate line of Supreme Court cases. In effect, requiring abstention in this context imposes a de facto exhaustion requirement as a prerequisite for federal court consideration of a $\S 1983$ claim. Judge Alarcon's opinion stated at its conclusion that the district court was required to abstain because "Harris has not given the California courts an opportunity to adjudicate his claim that the injection of lethal gas, in carrying out a sentence of death, violates the federal constitution." 55

But the Supreme Court has repeatedly and expressly rejected any requirement for exhaustion of state remedies prior to filing a $\$ 1983$ suit. In Monroe v. Pape, for example, the Court held: "The federal remedy is supplementary to the state remedy, and the latter need not be first sought and refused before the federal one is invoked." Similarly, in McNeese v. Board of Education, the Court declared that "relief under the Civil Rights Act may not be defeated because relief was not first sought under state law which provided a remedy." a state proceeding that challenged the gas chamber before he litigated the issue in federal court, and they suggest that the Ninth Circuit panel ignored and misapplied settled Supreme Court precedent.

We note that the panel could have approached justifying abstention in this context by focusing its attention on a state proceeding that was in fact pending: the habeas corpus petition in the California Supreme Court based on a claim of newly discovered evidence. ${ }^{58}$ However, while this fact implicates the Youn-

53. Gomez, 1992 U.S. App. LEXIS 7931, at **6-9.

54. The Ninth Circuit also relied on Pennzoil Co. v. Texaco Inc., 481 U.S. 1 (1987) as support. Id. at **7-8. However, like Huffman, Pennzoil expressly limits its holding to instances in which state proceedings are pending. The Court declared: "So long as those challenges relate to pending state proceedings, proper respect for the ability of state courts to resolve federal questions presented in state-court litigation mandates that the federal court stay its hand." 481 U.S. at 14.

55. Gomez, 1992 U.S. App. LEXIS 7931, at **8-9.

56. 365 U.S. 167, 183 (1961).

57. 373 U.S. 668, 671 (1963). In Patsy v. Board of Regents, the Court reconsidered the issue and held that "exhaustion of state administrative remedies should not be required as a prerequisite to bringing an action pursuant to $§ 1983$." 457 U.S. 496, 516 (1982).

58. Harris' Last Appeals, S.F. CHRON., Apr. 22, 1992, at A8. 
ger doctrine, close analysis suggests that the pendency of Harris' final state habeas petition could not properly have been used to legitimize abstention.

The linchpin of a Younger claim is that federal intervention unduly intrudes upon pending state court proceedings by generating "duplicative legal proceedings or disruption of the state criminal justice system." ${ }^{.59}$ The interference in state court proceedings can be direct, as in Younger, where the federal court was asked to enjoin the state from continuing its judicial process. Or the interference can be indirect, as where the federal court is asked to issue a declaratory judgment that might serve as a predicate for a future injunction and might de facto terminate the state court proceeding through res judicata. ${ }^{60}$

In this case, federal jurisdiction could not disrupt the state habeas proceeding because the subject matter of the two suits was completely different. The state proceeding involved a challenge to Harris' underlying criminal conviction based on allegedly newly discovered evidence of diminished responsibility; the federal suit involved solely a challenge to the State's proposed method of punishment. Resolution of the federal suit in Harris' favor would neither enjoin the state suit from proceeding nor de facto lead to its termination through res judicata. In short, the concerns underlying Younger are not triggered when the subject matter of the federal suit is unrelated to that of the state suit. ${ }^{61}$

For these reasons, even if the Ninth Circuit panel focused its attention on the existence of a coincident state habeas proceeding, the panel still should have found Younger abstention inappropriate in this context. ${ }^{62}$ Thus not only was

59. Steffel v. Thompson, 415 U.S. 452,462 (1974).

60. See Samuels v. Mackell, 401 U.S. 66 (1971) (Younger precludes federal court from granting declaratory judgment request by state court criminal defendant that would have res judicata effect of resolving case and ending litigation).

61. See, e.g., Deakins v. Monaghan, 484 U.S. 193 (1988) (Younger abstention does not apply to federal court suit for monetary relief by individuals who were criminal defendants in unrelated state court proceedings).

Indeed, even if the subject matter of the two suits were identical, Younger still should not apply. The doctrine has previously been applied only where the private party seeking federal intervention was defending against the imposition of state power in the state proceedings. Here, Harris initiated both the state and federal civil proceedings. Abstention based solely on identity of subject matter would mean that private parties could never "split" state and federal claims based on the same transaction by bringing the state claim in state court and the federal claim in federal court. But the Supreme Court has squarely rejected this conclusion. See, e.g., Moses H. Cone Memorial Hosp. v. Mercury Constr. Corp., 460 U.S. 1 (1983); Colorado River Water Conservation Dist. v. United States, 424 U.S. 800, 817 (1976).

62. Another more subtle approach that the panel could have taken but did not recognize involves res judicata: Harris arguably could have raised his gas chamber claim earlier in either federal or state proceedings; under principles of res judicata, each failure to do so independently bars the claim now. With respect to previous federal opportunities, however, this argument is unpersuasive for two reasons. First, res judicata consequences cannot attach to Harris' failure to raise the gas chamber claim in prior federal habeas proceedings because he could not have brought this claim in such proceedings; he had not satisfied the state exhaustion requirement by presenting the claim earlier in state court. See Rose v. Lundy, 455 U.S. 509 (1982); Ex parte Royall, 117 U.S. 241 (1886). Second, conventional res judicata principles do not apply to successive federal habeas actions, whose propriety is govemed rather by successive-petition and abuse-ofthe-writ principles. See Keeney v. Tamayo-Reyes, 112 S. Ct. 1715, 1723 (1992) (O'Connor, J., dissenting) ('Habeas corpus has always differed from ordinary civil litigation, however, in one important respect: The doctrine of res judicata has never been thought to apply.") (citing cases). 
the panel's stated rationale wrong, but its conclusion cannot easily be defended by more nuanced analysis.

Finally and most significantly, even if the Ninth Circuit panel were correct that Judge Patel ought to have abstained under Younger, the panel nevertheless acted improperly in ordering her to vacate her temporary restraining order. As the panel itself acknowledged, "[m]andamus is an extraordinary remedy that may be used to challenge an otherwise unappealable order if the district court's exercise of jurisdiction "was clearly erroneous as a matter of law." ${ }^{\text {" } 63}$ In fact, the Supreme Court recently said that it is "clearly erroneous" for a federal court to apply Younger abstention in the absence of pending state court proceedings. ${ }^{64}$ It is farcical to characterize Judge Patel's failure to abstain as "clear error." ${ }^{\text {IS }}$ Whatever the ultimate merit of the argument for abstention, the panel's failure to give proper deference to Judge Patel's decision reveals the panel's inclination to facilitate the execution rather than to be faithful to legal standards.

\section{B. The Supreme Court's Decision Vacating the Late Evening Stays}

As described above, two stays were issued at the request of ten Ninth Circuit judges to permit the possibility of en banc review of the panel decision. ${ }^{66}$ The Supreme Court quickly vacated both stays, stating in a brief per curiam opinion:

Harris brought a 42 U.S.C. $\S 1983$ action claiming that his execution by lethal gas is cruel and unusual in violation of the Eighth

Whether res judicata consequences attach to Harris' failure to raise the gas chamber claim in previous state habeas corpus proceedings tums on state law preclusion principles. As a general matter, habeas proceedings are understood not to generate typical claim preclusion consequences for the unsuccessful petitioner; instead, repeat litigation is governed by special successive-petition and abuse-of-the-writ rules. See In re Crow, 483 P.2d 1206, 1212 n.8 (Cal. 1971) (en banc) ("[T]he doctrine of res judicata would not bar the petitioner from seeking relief in habeas corpus after successive denials of his petitions .... The broad scope of the Great Writ and the fundamental right that it protects, prevent the application of the doctrine of res judicata to foreclose habeas corpus relief.") (citations omitted); cf. Keeney, 112 S. Ct. at 1723; Silverton v. Department of Treasury, 644 F.2d 1341 (9th Cir. 1981) (giving res judicata effect in subsequent $\$ 1983$ suit to previous state court habeas proceeding with respect to claims actually litigated), cert. denied sub nom. Silverton v. Regan, 454 U.S. 845 (1981). At a minimum, any reliance on res judicata principles to bar Harris' federal claim would require careful analysis of state preclusion law, an inquiry that the Ninth Circuit panel did not perform.

63. Gomez, 1992 U.S. App. LEXIS 7931, at *3 (quoting Bauman v. United States Dist. Court, 557 F.2d 650,654-55 (9th Cir. 1977)).

64. Ankenbrandt v. Richards, 112 S. Ct. 2206, 2216 (1992).

65. Professors Calabresi and Lawson argue persuasively that the Younger abstention doctrine ought to be understood as constraining federal courts' equitable remedial powers and not their jurisdiction. See Stephen G. Calabresi \& Gary Lawson, Equity and Hierarchy: Reflections on the Harris Execution, 102 YALE L.J. 255, 257-66 (1992). If they are correct that Younger itself imports an equitable balancing test, the Ninth Circuit panel's decision that Judge Patel committed clear error in issuing the temporary restraining order is all the more indefensible.

66. See supra text accompanying notes $25-26$. 
Amendment. This action ${ }^{67}$ is an obvious attempt to avoid the application of $\mathrm{McCleskey} v$. Zant to bar this successive claim for relief. Harris has now filed four prior federal habeas petitions. He has made no convincing showing of cause for his failure to raise this claim in his prior petitions.

Even if we were to assume, however, that Harris could avoid the application of $\mathrm{McCl}$ cleskey to bar his claim, we would not consider it on the merits. Whether his claim is framed as a habeas petition or $\S 1983$ action, Harris seeks an equitable remedy. Equity must take into consideration the State's strong interest in proceeding with its judgment and Harris' obvious attempt at manipulation. This claim could have been brought more than a decade ago. There is no good reason for this abusive delay, which has been compounded by last-minute attempts to manipulate the judicial process. A court may consider the last-minute nature of an application to stay execution in deciding whether to grant equitable relief.

The application to vacate the stay of execution of death is granted, and it is ordered that the orders staying the execution of Robert Alton Harris entered by the United States Court of Appeals for the Ninth Circuit ... are vacated. ${ }^{68}$

The Supreme Court thus did not consider the Ninth Circuit panel's Younger justification for mandating that the temporary restraining order be vacated. Rather, the Court gave two new reasons for vacating the stays: McCleskey precluded judicial review, and a stay was inappropriate based on equitable considerations. The first is an erroneous application of the law; the second reflects a skewed balancing of the equities.

\section{McCleskey v. Zant Does Not Apply}

In McCleskey v. Zant, the Supreme Court considered the ability of federal courts to dispose of successive habeas corpus petitions by the same inmate. ${ }^{69}$ The Court ruled that when a person has presented a habeas corpus petition to a federal court, a subsequent petition presenting a new issue may be heard only if the petitioner can show "cause and prejudice" for not having raised the matter earlier. ${ }^{70}$ The only exception to this rule occurs when the petitioner can show "a miscarriage of justice"-the "conviction of an innocent person."

67. The present version of the Court's opinion differs from that published contemporaneously with its decision. The opinion issued on April 21, 1992 originally began: "Harris claims that his execution by lethal gas is cruel and unusual in violation of the Eighth Amendment. This case . . . " See 60 U.S.L.W. 3733 (1992) (per curiam). In a highly unusual move, the Court issued an "amended" opinion on May 6, 1992 in which it altered the language as reflected in the text above.

68. Gomez v. United States Dist. Court, 112 S. Ct. 1652, 1653 (1992) (per curiam) (citations omitted).

69. 111 S. Ct. 1454 (1991).

70. The "cause and prejudice" test also is used to determine whether a habeas corpus petitioner can present claims not raised in the initial criminal trial in direct appeals from it. See Wainwright v. Sykes, 433 U.S. 72 (1977).

71. $111 \mathrm{~S}$. Ct. at $\mathbf{1 4 7 4 - 7 5 .}$ 
Court's analysis was confined entirely to analyzing the appropriate standard under federal habeas corpus law.

The Supreme Court stated in the Harris case that McCleskey barred Harris' $\S 1983$ claim because he had already presented four habeas corpus petitions to the federal courts; however, Harris' challenge to the means of carrying out his execution was not brought in the form of a petition for habeas corpus. Rather, it was a $\S 1983$ class action suit, with Harris as one class member, and McCleskey simply does not apply to $§ 1983$ litigation. The Supreme Court's unstated assumption in using $M c C l e s k e y$ was that Harris' claim properly should have been treated as a habeas petition. This treatment was unjustifiable; the Court had no authority to apply habeas corpus rules to a properly filed $\S 1983$ claim.

First, the class action lawsuit met all requirements for a $§ 1983$ suit. Section 1983 "creates a cause of action, a legal entitlement to relief, against those who, acting pursuant to state government authority, violate federal law." The plaintiffs clearly fulfilled these requirements by alleging that state officials were violating the Eighth Amendment by carrying out executions in the gas chamber.

Second, the suit did not fit under the judicially created exception to $\$ 1983$, which provides that the statute cannot be used by individuals seeking to end or shorten their period of confinement. ${ }^{73}$ In Preiser v. Rodriguez, New York state prisoners brought concurrent $\S 1983$ and habeas actions for restoration of good time credits that they claimed the State unconstitutionally revoked. The Court held that the prisoners' sole remedy was through habeas corpus: "[W] a state prisoner is challenging the very fact or duration of his physical imprisonment, and the relief he seeks is a determination that he is entitled to immediate release or a speedier release ... his sole federal remedy is a writ of habeas corpus." 74 The Court emphasized that challenges to conditions of confinement are actionable under $\S 1983$ without exhaustion of state remedies; only challenges seeking "immediate or more speedy release" cannot be brought via $\S 1983$ litigation. ${ }^{75}$ Indeed, federal courts have entertained hundreds of $\$ 1983$ claims challenging prison conditions and the nature of punishment. ${ }^{76}$

Harris was not seeking an "immediate or more speedy release," nor was he challenging the "very fact or duration of his physical imprisonment." Instead, he was objecting solely to the manner of his execution. Preiser does not preclude challenges to conditions of confinement; it should not be read as preventing challenges to the "conditions" of the execution. The Eleventh Circuit has distinguished Preiser on exactly this basis: "Appellant does not challenge the

72. ERWIN CHEMERINSKY, FEDERAL JURISDICTION $\$ 8.1$ (1989).

73. See Preiser v. Rodriguez, 411 U.S. 475 (1973).

74. Id. at 500 .

75. Id. at 494 .

76. See, e.g., Hudson v. McMillian, 112 S. Ct. 995 (1992); Hutto v. Finney, 437 U.S. 678 (1978). See generally SHELDON KRANTZ, THE LAW OF CORRECTIONS AND PRISONERS' RIGHTS (3d ed. 1986). 
fact or nature of his sentence or the state's right to execute him thus distinguishing this $\S 1983$ action from one brought under [the federal habeas corpus statute,] 28 U.S.C. $§ 2254 . "$ " 77

Therefore, Harris was entitled to bring a $\$ 1983$ suit challenging the method of his execution. The Court had no legal authority to recharacterize his suit as a habeas corpus petition to apply the McCleskey rule to bar review. ${ }^{78}$

Moreover, if the Court had authority to treat the case as a habeas corpus petition, it should have received briefing and argument as to whether "cause and prejudice" justified Harris' failure to raise the Eighth Amendment claim earlier. Under McCleskey, Harris could bring a successive habeas corpus petition if he could demonstrate good cause for not having raised the issue earlier and prejudice from being denied the chance to raise it now. ${ }^{79}$ Hence, if $M c$ Cleskey applied, a court should have considered carefully whether Harris' petition could be heard. The summary execution denied Harris the ability to satisfy the Court's own legal rule.

\section{The Court's Equitable Argument is Unconvincing}

The Supreme Court's alternative reason for vacating the Ninth Circuit's second and third stay orders addressed the right question but provided an

77. Sullivan v. Dugger, 721 F.2d 719, 720 (11th Cir. 1983).

78. Perhaps the Court was implicitly holding that McCleskey should be extended to apply to all $\$ 1983$ litigation raising issues that could have been litigated through a habeas corpus petition. There are, however, problems with such an extension of $M c C l e s k e y$. At the very least, it is troubling that the Court would impose such an extension without considering briefs or argument on the issue. Such a major change in the law is poorly accomplished by a late-night court order, without explanation or careful deliberation.

Moreover, such an extension of McCleskey would bar an enormous amount of $\S 1983$ litigation. Virtually all lawsuits brought by prisoners, such as those challenging the conditions of confinement, could be presented in habeas corpus petitions. $C f$. Campbell v. Magruder, 416 F. Supp. 100 (D.D.C. 1975), aff' $d$ in part and remanded, 580 F.2d 521 (D.C. Cir. 1978); Miller v. Carson, 401 F. Supp. 835 (M.D. Fla. 1975), aff'd in part and modified in part, 563 F.2d 741 (5th Cir. 1977); James v. Wallace, 382 F. Supp. 1177 (M.D. Ala. 1974) (examples of federal court rulings remedying abusive, unconstitutional prison conditions). If $\mathrm{McCl}$ leskey is extended to hold that $\S 1983$ can never be used to present matters that could have been brought on habeas corpus, none of this litigation would be possible under $\S 1983$. There are obvious separation of powers problems when a judicially created rule, McCleskey, is used to nullify statutory authority, such as $\S 1983$.

79. Harris might have argued that changes in state laws conceming the use of lethal gas meant that the claim had only recently gained merit. See infra text accompanying notes 84-94. In other cases the Supreme Court has recognized a change in the legal circumstances as sufficient "cause" to allow a new issue to be raised on habeas corpus. See Reed v. Ross, 468 U.S. 1 (1984) (just cause exists where petition presents new legal claims based on changes in law that were not reasonably available to counsel at time of earlier trial). But see Teague v. Lane, 489 U.S. 288 (1989) (petitioner cannot invoke "new rule" of law in support of habeas relief except in exceptional circumstances). Teague arguably would not bar Harris' claim if presented in a habeas petition. One of the exceptional circumstances recognized by Teague includes "certain kinds of primary, private individual conduct beyond the power of the criminal law-making authority to proscribe." Id. at 307 . Harris contended that it is beyond the authority of the government to execute him in the gas chamber. Moreover, the appropriate time for determining whether an execution is cruel and unusual punishment is at the time of the execution, not when the state conviction becomes final. Therefore, the law prevailing at the time of sentencing is not the appropriate focus. 
oversimplified and ultimately unpersuasive answer. As noted above, the Court reasoned that:

Harris seeks an equitable remedy. Equity must take into consideration the State's strong interest in proceeding with its judgment and Harris' obvious attempt at manipulation .... A court may consider the lastminute nature of an application to stay execution in deciding whether to grant equitable relief. ${ }^{80}$

The Rehnquist Court's impression that death-sentenced prisoners frequently wait without justification until the "last minute" to bring a barrage of legal claims in the hope of forestalling their executions lies at the core of the Court's disdain for such claims. ${ }^{81}$ We do not countenance intentional delay in raising legal challenges solely for the purpose of manipulating the judiciary into an unwarranted stay of execution. ${ }^{82}$ However, as Robert Harris' story illustrates, this Court lately has become all too flippant with its unreflective accusations of litigant tardiness. Assuming that Harris' gas chamber challenge "could have been brought more than a decade ago," ${ }^{~} 83$ the Court's decision to penalize Harris for delay by barring the claim presumed that Harris ought to have brought the claim earlier rather than later-so much so that his wrong choice deserved the procedural equivalent of the death penalty. But given the precise nature and context of Harris' substantive claim, his decision to delay adjudication was quite justifiable.

On the merits, Harris maintained that execution by gas chamber violates the prohibition on cruel and unusual punishments. This prohibition "recognizes the "evolving standards of decency that mark the progress of a maturing society." " In discerning these evolving standards, the Court has "looked to objective evidence of how our society views a particular punishment today. The clearest and most reliable objective evidence of contemporary values is the legislation enacted by the country's legislatures. ${ }^{85}$

80. Gomez v. United States Dist. Court, 112 S. Ct. 1652, 1653 (1992).

81. See Sawyer v. Whitley, 112 S. Ct. 2514, 2520 \& n.7 (1992) ("[W]e regard it as a regrettable fact" that "[i]n the every day context of capital penalty proceedings, a federal district judge typically will be presented with a successive or abusive habeas petition a few days before, or even on the day of, a scheduled execution.").

82. The Court recently has lamented "efforts on the part of habeas petitioners to delay their filings until the last minute with a view to obtaining a stay because the district court will lack time to give them the necessary consideration before the scheduled execution." Id. at $2520 \mathrm{n} .7$. To the extent one believes that lower court judges improperly resolve doubts in favor of postponing death, this concern can be met adequately by requiring demonstration of a greater likelihood of success on the merits for last-minute stay requests; such requests need not be rejected automatically. In Harris' case, given the straightforward and purely legal nature of the constitutional challenge, Judge Patel's reasoned conclusion that Harris' claim was substantial cannot be discounted as forced prematurely by the pressure of a deadline.

83. Gomez, 112 S. Ct. at 1653.

84. Penry v. Lynaugh, 492 U.S. 302, 330-31 (1989) (quoting Trop v. Dulles, 356 U.S. 86, 101 (1958) (Warren, C.J., plurality)).

85. Id. at 331 (citation omitted); see also Stanford v. Kentucky, 492 U.S. 361, 370-373 (1989) (focusing on current state statutes as indicia of "evolving standards of decency"). 
Harris' success on the merits turns on the significance of the fact that contemporary legislation "exhibit[s] a nearly universal rejection of [this] means of execution." ${ }^{\text {"86 }}$ In the late 1970's, eleven states employed the gas chamber; by 1983 this number had dwindled to seven. That year, Justices of the Supreme Court raised concerns about the constitutionality of this mode of execution. ${ }^{87}$ Thereafter, four of the seven states abandoned the use of the gas chamber, leaving California among the three holdouts. ${ }^{88}$ Maryland has not executed anyone since the Supreme Court upheld the constitutionality of some death penalty statutes in $1976 .{ }^{89}$ Arizona executed Donald Harding on April 6, 1992, just two weeks prior to Harris' scheduled execution. ${ }^{90}$ Reacting to accounts of this execution, Arizona's Attorney General immediately recommended that Arizona abandon the gas chamber as well. ${ }^{91}$ Given this recent yet pronounced historical trend, Harris' position on the merits became significantly stronger over the past decade and gained measurable force from Arizona's experience a mere two weeks prior to Harris' scheduled execution. ${ }^{92}$

This nexus between recent historical developments and likely success on the merits renders specious the Court's proclamation that "there is no good reason" for Harris not to have brought the claim "more than a decade ago."

86. Gomez, 112 S. Ct. at 1655 (Stevens, J., dissenting).

87. See Gray v. Lucas, 463 U.S. 1237, 1240-47 (1983) (Marshall, J., dissenting from denial of certiorari).

88. See supra note 15.

89. See Gregg v. Georgia, 428 U.S. 153 (1976) (upholding Georgia death penalty statute).

90. See Gruesome Death in Gas Chamber Pushes Arizona Toward Injections, N.Y. TMES, Apr. 25, 1992 , at 9.

91. Gomez, 112 S. Ct. at 1654 \& n.6 (Stevens, J., dissenting) (describing Attorney General's position and referring to bill that mandated abandonment of gas chamber, pending before Arizona Legislature).

92. This is evidenced by Justice Stevens' reliance on the Arizona experience in his dissent from the Court order vacating the stays. Id.

We do not address the ultimate merit of Harris' Eighth Amendment claim. We do, however, question Professors Calabresi and Lawson's heavy reliance, in concluding the claim lacks merit, on the size of the three states still using the gas chamber and the motivation of the four states recently abolishing it. See Calabresi \& Lawson, supra note 65, at 268-69. It is particularly difficult to imagine, for example, Justice Scalia inquiring into the unarticulated motivation of state legislatures rather than merely focusing on the state of actual legislation when determining whether a punishment is "unusual" within the legal landscape. Cf. Stanford v. Kentucky, 492 U.S. 361,369 (1989) (judgment of constitutionality "should be informed by objective factors to the maximum possible extent") (citation omitted); Penry v. Lynaugh, 492 U.S. 302, 335 (1989) (legislation is "an objective indicator of contemporary values upon which we can rely") (emphasis added).

For present purposes, we simply observe that Professors Calabresi and Lawson's insistence that the Eighth Amendment claim was a loser has no doctrinal bearing on the propriety of Judge Patel's decision to stay the execution for ten days pending a plenary hearing on the merits of the claim. Neither Professors Calabresi and Lawson nor the Supreme Court ever challenge (at least explicitly) the district court's finding that in 1992 the claim raised "serious questions going to the merits." See supra text accompanying note 11. Given this finding, Harris was entitled to a temporary restraining order if the "balance of hardships tipp[ed] in his favor." See supra text accompanying note 10. To the extent that this latter question requires evaluating whether Harris inexcusably delayed litigation, the proper inquiry is whether the claim gained significant force over time in a relative sense, not whether the claim would ultimately succeed in an absolute sense. Profesors Calabresi and Lawson's argument that delay was unjustified because the claim was a Ioser thus improperly conflates the issue of likelihood of success with the separate issue of equitable balance of hardships.

93. See supra text accompanying notes $81-83$. 
Any competent attorney would develop his or her clients' legal claims to their greatest potential (both legally and factually) and would litigate those claims in the optimal combination of time and place. If Robert Harris and his counsel were prescient enough in 1982 or 1983 to recognize that the legal and factual basis for the gas chamber claim would likely mature over time given society's "evolving standards of decency," is it truly fair to sanction Harris for not raising the claim earlier when it would have been a sure loser due to its immaturity? The Court's determination that Harris dirtied his hands through delay and thereby forfeited the opportunity to litigate his claim essentially punishes Harris for what in other contexts would be applauded as appropriate advocacy. ${ }^{94}$

Moreover, Harris' decision to delay his challenge to the gas chamber until its use was imminent also advanced an important institutional interest of the federal judiciary. A bedrock principle of federal jurisdiction, particularly lauded by opponents of an activist judiciary, is that whenever possible federal courts ought to avoid unnecessary constitutional rulings. This principle animates both the Article III "ripeness" requirement for federal adjudication" and a host of prudential techniques for avoiding unnecessary decisions. ${ }^{96}$

94. Conceding arguendo this evolution of the merits of Harris' gas chamber claim, Professors Calabresi and Lawson raise a fascinating question conceming whether the propriety of Harris' timing ought to be assessed from an ex ante or ex post perspective, i.e., before or after the evolution took place. See Calabresi \& Lawson, supra note 65 , at 267 . Their judgment that "the claim should have been brought within a reasonable time of its accrual," id., suggests that the determination of whether a sentence is "cruel and unusual" rests on the law at the time of sentencing and that subsequent legal developments are irrelevant. Our analysis suggests that the determination should be made at the time when punishment is imposed. Given the law's express recognition that constitutionality turns on "evolving standards" of decency, the latter perspective seems more consistent with doctrine. It is difficult to articulate what interest a state can claim in imposing a punishment that is considered unconstitutional when administered.

In any event, the fact that this debate remains unresolved itself justifies Harris' delay and Judge Patel's temporary restraining order. Given both that Harris' claim was stronger in 1992 than when the sentence was imposed and the lack of any precedent suggesting that the constitutionality of a sentence ought to be determined at the time of sentencing rather than at the time of imposition, Harris was justified in waiting until his claim was at its strongest and in urging the court to embrace what Professors Calabresi and Lawson call the ex post approach.

95. Article III precludes federal courts from entertaining claims for relief from potential injuries whose likelihood of occurrence is "speculative" as opposed to "real and immediate." See, e.g., Whitmore v. Arkansas, 495 U.S. 149, 155 (1990) (quoting Los Angeles v. Lyons, 461 U.S. 95, 102 (1985)); Babbitt v. United Farm Workers Nat'l Union, 442 U.S. 289, 298 (1979); Gene R. Nichol, Jr., Ripeness and the Constitution, 54 U. CHI. L. REV. 153 (1987) (describing Burger Court's emphasis on actual injury as key to ripeness requirement under Article III). Contemporary ripeness doctrine embraces a prudential component as well: federal courts generally refuse to entertain claims where delayed adjudication would ensure the beneficial development of a more concrete factual record. See, e.g., Regional Rail Reorganization Act Cases, 419 U.S. 102, 143 (1974) ("[T]here are situations where, even though an allegedly injurious event is certain to occur, the Court may delay resolution of constitutional questions until a time closer to the actual occurence of the disputed event, when a better factual record might be available.").

96. See, e.g., Rescue Army v. Municipal Court of Los Angeles, 331 U.S. 549, 570 n.34 (1947) ("“If there is one doctrine more deeply rooted than any other in the process of constitutional adjudication, it is that we ought not to pass on questions of constitutionality . . . unless adjudication is unavoidable.' It has long been the Court's 'considered practice not to decide ... . any constitutional question in advance of the necessity for its decision. . . .") (quoting Alabama State Fed'n of Labor v. McAdory, 325 U.S. 450, 461 (1945) and Spector Motor Serv. v. McLaughlin, 323 U.S. 101, 105 (1944)). 
By its original sentence, California manifested its intention eventually to execute Harris. But during the past decade, it remained quite possible that Harris would never actually be executed. During this time Harris litigated various grounds for reversing his conviction or modifying his sentence ${ }^{97}$ and also petitioned for executive clemency. ${ }^{98}$ Moreover, in light of other states' replacement of the gas chamber with other means of execution, it was unclear whether the gas chamber would still be California's prescribed means of execution by the time Harris' appeals were exhausted. For these reasons, adjudication of the gas chamber claim at an earlier time might have been wholly unnecessary or premature. Hence, while perhaps Harris' claim would have satisfied Article III ripeness requirements a decade ago, it is clear that Harris' decision to delay litigation served, if unintentionally, to advance the federal judiciary's institutional interest in self-restraint. ${ }^{99}$

One might respond that, even if Harris justifiably withheld his claim a decade ago, he nevertheless crossed a line by waiting until four days before his scheduled execution. But precisely where was this line? It is quite difficult, without being arbitrary, to pick out a particular point in time in the previous decade where delay suddenly turned from beneficial to abusive. Given that Harris' claim did not fully mature until the Arizona execution two weeks prior to his own scheduled execution and that arguably the imminence of his death by a particular technique became "real and immediate" only after Governor

97. Anyone familiar with the Califomia state courts' consistent track record of setting aside death sentences during much of this period certainly would not have bet heavily that Harris would one day leave death row through the short route. See Scott G. Parker \& David P. Hubbard, Comment, The Evidence for Death, 78 CAL. L. REV. 973, 978-79, 979 n.35 (1990) (highest state court affirmed conviction and death sentence in only three of 61 capital appeals between 1977 and 1986).

98. Dan Morain \& Daniel M. Weintraub, Wilson Rejects Plea of Mercy for Harris, L.A. TMME, Apr. 17, 1992, at A1.

99. Professors Calabresi and Lawson quite ably defend the general relevance of such institutional concerns in balancing the equities. See Calabresi \& Lawson, supra note 65, at 257-66 (arguing that federalism and separation of powers values ought to inform equitable calculation).

The Court's condemnation of Harris' delay also necessarily presumes that if Harris had raised and the federal courts had rejected the gas chamber claim ten years ago, principles of finality and res judicata would have barred him from relitigating the claim now notwithstanding subsequent historical events. This assumption is questionable. Pursuant to Fed. R. Civ. Proc. $60($ b)(6), Harris might have been permitted to attack directly the continuing validity of a ten-year-old judgment affirming California's power to employ the gas chamber. See, e.g., Cox v. Wyrick, 873 F.2d 200, 201 (8th Cir. 1989) (change in relevant law may warrant reopening final judgment), cert. denied sub nom. Cox v. Armontrout, 493 U.S. 832 (1989); JAMES W. MOORE \& Jo D. LUCAS, 7 MOORE's FEDERAL PRACTICE ๆ 60.27[2], at 60-274 (2d ed. 1992) (Fed. R. Civ. Proc. 60(b)(6) is "means for accomplishing justice in exceptional situations"). Moreover, Harris might have been permitted to bring a second lawsuit raising the same claim and avoided claim preclusion by invoking a narrow exception encompassing circumstances where evolving case law provides a new right of action not previously available to the losing litigant. See IB MOORE \& LUCAS, supra, I 0.415; see also ChaRles A. WRIGHT ET AL., FEDERAL PRACTICE AND PROCEDURE $\$ 4415$ (citing several cases in which courts deny preclusive effect of final judgment on public interest grounds).

If Harris could have relitigated his gas chamber claim after having lost it ten years ago, no state or federal interest would have been served by requiring him originally to have brought the claim long ago. Given any reasonable uncertainty as to Harris' ability to relitigate, both governments arguably benefitted from Harris' decision to wait and burden the federal courts only once with his challenge-at the moment of primary relevance. 
Wilson denied his petition for clemency, Harris' filing the very next day seems a reasonable choice along this timeline. Ultimately, therefore, the Supreme Court's flip assertion that Harris engaged in "abusive delay ... compounded by last-minute attempts to manipulate the judicial process" 100 is at best suspect.

Even if the Court's perjorative characterization of Harris' behavior were in fact fair, it still would not follow that Harris deserved to forfeit his equitable claim for relief in the form of a temporary stay of execution pending resolution of his gas chamber challenge. The Court's myopic focus on this single fact is not faithful to established case law governing the propriety of a stay, which requires consideration of three factors: (1) whether denial of a stay will visit irreparable harm on the proponent; (2) whether issuance of the stay will significantly injure the opponent and/or the public interest; and (3) whether the proponent is likely to prevail on the merits. ${ }^{101}$ The Court's concern about the timing of Harris' lethal gas claim does not fit comfortably into this inquiry; rather, it reflects in more base terms a valuation of finality over fairness which cannot be justified in this context.

Death is the ultimate sanction. Although Harris was challenging how, not if, his life would be taken by the State, a "slow, painful, and torturous" death ${ }^{102}$ would clearly visit upon him an irreparable harm. And the district court's finding that Harris raised a serious question on the merits was not disputed by any higher court throughout the litigation. The Court's decision to vacate the Ninth Circuit's stays, therefore, could be justified only if necessary to avoid significant injury to the State or the public interest.

Not only did the Court fail to explain its judgment; more importantly, its judgment cannot persuasively be defended. The State cannot claim to be injured in any tangible way by the prospect of a ten-day delay pending district court resolution of the constitutional issue. ${ }^{103}$ Rather, the Court is concerned with a harm better described as conceptual or perhaps psychological: the longer the execution is delayed, the longer the State is prevented from vindicating its "strong interest in proceeding with its judgment." ${ }^{104}$ But why should this

100. Gomez v. United States Dist. Court, 112 S. Ct. 1652, 1653 (1992).

101. See also Barefoot v. Estelle, 463 U.S. 880, 895-96 (1983); Rostker v. Goldberg, 448 U.S. 1306, 1308 (1980) (Brennan, J., in-chambers opinion). The Court has in the past noted that it "generally places considerable weight on the decision [about the propriety of a stay] reached by the court of appeals" in considering whether to grant or vacate a stay of execution. Barefoot, 463 U.S. at 896 . In recent years, however, this pattern of deference has largely disappeared. See, e.g., Demosthenes v. Baal, 495 U.S. 731 (1990); Delo v. Stokes, 495 U.S. 320 (1990).

102. Fierro v. Gomez, 790 F. Supp. 966, 970-71 (N.D. Cal. 1992).

103. Indeed, it is difficult to identify what tangible harm the State would suffer even were Harris to win his challenge on the merits. The State would merely have to adopt a different manner of execution. This is simply not a situation in which success of the proponent's claim would necessitate retrial, and years of delay might undermine the State's ability to mount a second successful prosecution.

104. Gomez, 112 S. Ct. at 1653; see also In re Blodgett, 112 S. Ct. 674, 676 (1992) (stay of execution "has prevented [the State] from exercising its sovereign power to enforce the criminal law, an interest we found of great weight in McCleskey"). 
concern outweigh that of imposing irreparable injury in violation of the Constitution?

Death penalty proponents feel strongly that the deterrence and retribution justifications for state-sponsored executions are frustrated by long timespans between pronouncement and imposition of sentence. Delay may also anger and frustrate various individuals such as family survivors of murder victims. Perhaps these public and private interests are sufficiently weighty to justify streamlining the appellate process in a manner that is both efficient and fair. ${ }^{105}$

These interests, however, do not justify refusal to hear a substantial constitutional claim merely because such a process would occasion minor delay. The very nature of constitutional guarantees to the accused requires that the public and private interests in swift retribution be tempered by concerns for accuracy and fairness; the ultimate goal is lawful punishment, swift and sure. As the Court once explicitly recognized: "[ $t]$ here is little societal interest in permitting the criminal process to rest at a point where it ought properly never to repose."106 Given Harris' substantial claim that the gas chamber inflicts unnecessary pain such that it is "incompatible with 'the evolving standards of decency that mark the progress of a maturing society," 107 according greater priority to the local and momentary pressure for Harris' immediate execution seems ironic. Thus the Court's unarticulated calculus that the public and private interest in finality is sufficiently weighty to justify imposing a clearly irreparable injury on Harris does not withstand dispassionate scrutiny. ${ }^{108}$ Given the

105. Much of the delay between pronouncement and imposition of sentence is caused by the State's own slow timetables and its failure to ensure that defendants receive constitutionally adequate representation. In California, for example, death sentences are automatically appealable to the California Supreme Court, and the period between sentencing and direct appeal averages six years. This is due in part to the dearth of attorneys capable and willing (given paltry State-paid fees) to represent inmates sentenced to death. Robert Egelko, Politics at the Gallows, CAL. LAW., June 1992, at 19.

106. Mackey v. United States, 401 U.S. 667, 693 (1971) (Harlan, J., concurring).

107. Estelle v. Gamble, 429 U.S. 97, 102 (1976) (quoting Trop v. Dulles, 356 U.S. 86, 101 (1958) (Warren, C.J., plurality)).

108. As Professors Calabresi and Lawson ably explain in their reevaluation of Younger abstention as an equitable doctrine, Calabresi \& Lawson, supra note 65, at 257-66, equity inherently involves a balancing of competing interests. We strongly disagree with their conclusion that the Supreme Court struck the right balance here. On one side of the balance is the interest of the individual, and of society, in ensuring that executions are conducted in accordance with the Constitution. Even ardent supporters of the death penalty surely recognize this interest, yet Professors Calabresi and Lawson give little weight to this factor.

The other side of the balance is the state's interest in proceeding with the execution. While Professors Calabresi \& Lawson do suggest in the abstract that "federalism" interests ought to be weighed on this side of the ledger, they do not explain how such interests become concrete in the context of the Harris case. Federalism interests that might cause a federal court to hesitate before enjoining an ongoing state proceeding are not implicated here, where the state proceedings have terminated. Professors Calabresi and Lawson also fail to identify any other specific, tangible ways in which the State of California is harmed by postponing the execution for ten days or even two months. Rather, Professors Calabresi and Lawson suggest merely that delay in bringing a claim, by itself, is "an eminently sensible ground for denying an injunction." Id. at 266. But the equitable principle of laches-the concept upon which Professors Calabresi and Lawson implicitly rely - does not regard delay as sufficient by itself to justify denial of injunctive relief. On the contrary, equitable relief is denied only if the plaintiff's delay imposes hardship upon the opposing party. Hence Professors Calabresi and Lawson's failure to articulate the hardships that delay would impose upon 
district court's unquestioned finding that Harris raised a serious constitutional question, the State's interest in immediate execution should hardly have been the paramount concern. ${ }^{109}$

\section{The Supreme Court's Injunction Against Any Further Stays}

The Supreme Court's final act in this legal drama further illustrates its utter disregard for careful legal analysis in the course of facilitating Robert Harris' death. As the Court vacated the final stay of execution entered by Ninth Circuit Judge Harry Pregerson, the Court proclaimed that "No further stays of Robert Alton Harris' execution shall be entered by the federal courts except upon order of this Court."110 The Court did not explain, let alone justify, its authority to issue this blanket prospective injunction aimed at the entire federal judiciary. Nor did the Court defend the propriety of exercising any such authority in the context of this case. The directness and brevity of the Court's single sentence sent the clearest message possible: Robert Harris must die. But the clarity of this message cannot obscure its disquieting subtext. At worst, the Court lacks legal authority to issue such a blanket injunction; at best, the Court exercised any such authority in an inappropriate and impertinent manner, reflecting frustration and anger-not reason.

The breadth of the Court's order is both extraordinary and unprecedented. The prospective injunction barred issuance of a stay on any legal grounds whatsoever, not merely on the asserted unconstitutionality of the gas chamber. It covered all future potential claims and cases. For example, Harris' close brush with death at 3:51 a.m. might conceivably have prompted his brother (or someone else), out of crystallized feelings of guilt, to reveal exculpatory information about Harris' role in his criminal activity. Even more hypothetically, the California legislature might have met in an emergency session and altered the legal mode of execution from cyanide gas to public hanging (or some other clearly objectionable punishment). The likelihood of such new claims was quite small, but the Supreme Court's sweeping preclusion of all claims underscores the conclusion that a broader constraint on future federal judicial action can hardly be imagined.

Even those who empathize with the Supreme Court's apparent frustration with Harris' last-minute stay activity should find the Court's final order disturbing. The order, precluding lower courts from exercising powers expressly granted them by congressional statutes, raises a substantial separation of powers

the State renders their argument incomplete.

109. Various studies by federal judges and legal defense organizations in the past ten years have concluded that federal appellate courts find constitutional flaws in $40 \%$ to $73 \%$ of state death penalty cases reviewed on the merits. See Marcia Coyle et al., Trial and Error in the Nation's Death Belt: Fatal Defense, NAT'L L.J., June 11, 1990, at 30.

110. Vasquez v. Harris, 112 S. Ct. 1713, 1714 (1992). 
concern. By statute, lower federal courts are authorized to issue stays of execution both in habeas cases ${ }^{111}$ and in civil actions brought pursuant to $\$ 1983 .{ }^{112}$ The All Writs Act authorizes all federal courts to "issue all writs necessary or appropriate in aid of their respective jurisdictions. . .."113 The Supreme Court's injunction effected a de facto suspension of the operation of these statutes with respect to Harris.

While in recent years the Court periodically has vacated individual stays of execution already issued by judges possessing jurisdiction over existing cases, this practice is a far cry from managing prospectively the federal judiciary's docket. The only plausible statutory basis for the Court's order for a blanket prospective injunction is the All Writs Act, which authorizes the Court to grant petitions for extraordinary writs such as mandamus and prohibition. ${ }^{114}$ The only other plausible basis is the Court's nonstatutory, nebulous "supervisory power" over the administration of justice in the federal courts. Neither potential source, however, justifies the Court's actions in this case.

The All Writs Act provides: “The Supreme Court and all courts established by Act of Congress may issue all writs necessary or appropriate in aid of their respective jurisdictions and agreeable to the usages and principles of law."115 This Act authorizes the Court to issue writs of mandamus in its exercise of appellate jurisdiction to correct an error of a lower federal court. However, the "remedy of mandamus is a drastic one, to be invoked only in extraordinary situations."116 The Harris situation does not qualify.

Writs of mandamus are typically justified only in two types of extreme situations relevant to the Harris case: ${ }^{117}$ (1) where necessary to compel an inferior court to comply with the prior judgment and mandate of an appellate court; ${ }^{118}$ and (2) where necessary "'to confine an inferior court to a lawful exercise of its prescribed jurisdiction or to compel it to exercise its authority

111. See 28 U.S.C. § 2251 (1988); see also Rule 4, Rules Governing Section 2254 Cases in the United States District Courts, 28 U.S.C. foll. $\$ 2254$ (1988).

112. See 42 U.S.C. $\$ 1983$ (1988) (authorizing both legal and equitable remedies).

113. 28 U.S.C. \$ 1651(a) (1988).

114. 28 U.S.C. $\$ 1651$. Technically, a writ of mandamus compels a lower court to do something it has refused to do, and a writ of prohibition prohibits the court from doing something it otherwise will do. However, since almost any question of power may be phrased either affirmatively or negatively, these writs are often used interchangeably. For simplicity, the Supreme Court's blanket injunction may be analogized to a writ of mandamus directing lower courts to refrain from entering a stay of execution for Harris.

115. Id.

116. Kerr v. United States Dist. Court, 426 U.S. 394, 402 (1976); see also Will v. United States, 389 U.S. 90, 95 (1967).

117. The Supreme Court has held that "where a case is within the appellate jurisdiction of [a] higher court a writ of mandamus may issue in aid of the appellate jurisdiction which might otherwise be defeated by the unauthorized action of the court below." McClellan v. Carland, 217 U.S. 268, 280 (1910). Since the Court's aim by its blanket injunction here was to ensure Harris' execution, thus mooting any need for the further exercise of its appellate jurisdiction, the injunction ordered cannot be grounded on this basis.

118. See Vendo Co. v. Lektro-Vend Corp., 434 U.S. 425, 427-28 (1978) (mandamus available to party who has prevailed in Supreme Court where lower court "does not proceed to execute the mandate, or disobeys and mistakes its meaning") (quoting United States v. Fossatt, 62 U.S. (21 How.) 445, 446 (1859)). 
when it is its duty to do so.'. . [O]nly exceptional circumstances amounting to a judicial 'usurpation of power' will justify the invocation of this extraordinary remedy." 119 In the present case, therefore, a writ of mandamus could have been justified only if the writ was necessary to preempt outright judicial disobedience or defiance of the Supreme Court's prior order and opinion vacating the second and third Ninth Circuit stays. It surely would have been inappropriate for the Court to presume, without compelling evidence, that federal judges would engage in lawlessly obstructionist behavior, and the Court could not fairly have interpreted Judge Pregerson's issuance of a fourth stay as evidence of such insolence.

After the Supreme Court invoked McCleskey and treated Harris' suit as if it were a habeas action rather than a $\$ 1983$ action, Harris apparently requested that Judge Pregerson do the same. In response to Harris' request, Judge Pregerson issued a one-day stay of execution. He later published a stay order explaining that "[a]s such, Harris" habeas petition contains unexhausted claims," $" 120$ referencing the doctrinal requirement that federal habeas petitioners must first exhaust available state remedies. ${ }^{121}$ Judge Pregerson's one-day stay thus purportedly functioned "to permit presentation of Harris' claims to the California Supreme Court."122

Given the rationale underlying the Supreme Court's recent order vacating the prior stays, invocation of the exhaustion doctrine as a basis for granting a stay appears misguided. ${ }^{123}$ However, the stay may be defended on an alternative basis: The federal judiciary has an institutional interest in ensuring that litigants with federal claims are not harshly penalized for reasonably invoking a federal forum before a state forum, although wrongly in hindsight. Prior to the Supreme Court's recharacterization of Harris' challenge as a habeas claim, prevailing rules applicable to $\$ 1983$ claims did not fairly apprise Harris of any requirement that he should present his constitutional challenge to the California courts. ${ }^{124}$ Harris' choice of a federal forum was both legally sound and strate-

119. Will, 389 U.S. at 95 (citations omitted).

120. Harris v. Vasquez, No. 92-70237 (9th Cir. April 21, 1992) (Pregerson, J.) (issuing stay).

121. This exhaustion requirement is designed to promote comity and federalism by prohibiting federal judicial intervention until after the state courts have had an initial opportunity to consider and correct their own alleged violations of federal law. To effectuate this deference, a federal court presented with a habeas petition containing an unexhausted claim ordinarily must dismiss the petition pending presentation of the claim to the appropriate state court. See Rose v. Lundy, 455 U.S. 509, 518 (1982).

122. Harris, No. 92-70237, slip op. at 1 (citations omitted).

123. The Supreme Court had just clearly stated that Harris' delay in presenting his challenge to Califomia's method of execution precluded the federal courts ever from considering it. The exhaustion requirement thus no longer could serve its usual purpose; there was no threat that a federal court would act to cure the alleged constitutional violation before the state courts could do so.

In faimess to Judge Pregerson, it is unclear whether he had access to the Supreme Court's recent reasoning by the time he published his stay order. Apparently he was unaware of the Court's analysis when he actually issued the stay. See Reinhardt, supra note 19, at [8-9].

124. See supra note 56 (no general exhaustion of state remedies requirement in $\S 1983$ cases). 
gically sensible. ${ }^{125}$ Although discrete jurisdictional doctrines sometimes allocate federal claims to state courts for initial adjudication, equitable rules should be designed to avoid penalizing litigants who first invoke a federal forum because the allocational principle is unclear. Any penalty would discourage uncertain litigants from exploring the federal route; this would undermine the federal courts' institutional interest in protecting their de facto "jurisdiction to determine jurisdiction" in grey areas. ${ }^{126}$ Since the allocational rule governing Harris' claim announced by the Supreme Court was unforeseeable (because inaccurate), ${ }^{127}$ Judge Pregerson's issuance of a one-day stay in order to protect Harris' ability to seek relief from the California Supreme Court nicely served this narrow federal interest.

Of course, Judge Pregerson did not expressly justify his stay order on this basis; our analysis reflects a post hoc rationalization. But for the present purpose of evaluating the Supreme Court's conduct, the relevant question is whether Judge Pregerson's stay ought to have been perceived as a "judicial "usurpation of power"' signaling a likely pattern of defiance sufficient to "justify the invocation of this extraordinary remedy" of mandamus. ${ }^{128}$ At 5:45 a.m. p.d.t. when the Supreme Court vacated the stay and issued its prospective injunction, the Court apparently was unaware of Judge Pregerson's actual or articulated motivation, and therefore the Court had no basis for presuming he was acting on an obstructionist impulse. In addition, the Court should have recognized that the stay order, however motivated, constituted a sensible and fair response to jurisdictional uncertainty. Thus, the Supreme Court could not fairly find the threshold level of judicial defiance necessary to support invocation of its mandamus power.

But even if Judge Pregerson's actions reasonably foreshadowed a pattern of continuous defiance, it would still be evident that the unprecedented scope of the Supreme Court's mandamus-like order reflects anger and not reason. The Court's order does not merely prohibit lower federal courts from issuing any further stays in Harris' $\$ 1983$ action based on his gas chamber challenge, but

125. As a strategic matter, Harris' decision not to pursue the identical civil claim simultaneously in two court systems saves resources and perhaps avoids the possibly adverse effect of res judicata principles on the federal litigation in the event that the state litigation proceeded to judgment first. See, e.g., Migra v. Warren City Sch. Dist., 465 U.S. 75, 84 (1984). But see supra note 62 (suggesting that state habeas proceedings, unlike conventional civil suits, generate no res judicata implications for subsequent litigation). In addition, Harris cannot be chided for selecting the federal forum as his first choice. See generally Erwin Chemerinsky, Parity Reconsidered: Defining a Role for the Federal Judiciary, 36 UCLA L. REV. 233 (1988); Burt Neuborne, The Myth of Parity, 90 HARV. L. REv. 1105 (1977).

126. This interest, for example, is exhibited in the federal courts' authority to dismiss without prejudice federal habeas petitions containing unexhausted state claims. See Rose v. Lundy, 455 U.S. 509, 522 (1982). For related institutional protections in contexts of unclear allocational principles, see, for example, 28 U.S.C. $\S 1367$ (d) (1990) (if federal court entertaining federal claim determines that exercise of supplemental jurisdiction over pendent state claim is inappropriate, applicable statute of limitations in subsequent state court action is tolled so that litigant is not disadvantaged for having attempted to invoke federal forum first).

127. See supra notes 123-24 and accompanying text.

128. Will v. United States, 389 U.S. 90, 95 (1967) (quoting De Beers Consol. Mines, Ltd. v. United States, 325, U.S. 212, 217 (1945)). 
also extends to all new claims raised in all new actions. As discussed earlier, it is certainly conceivable that new claims might exist whose adjudication would not conflict with the principles articulated in the Court's order vacating the second and third stays; ${ }^{129}$ indeed, the Court's acknowledgment that it retained for itself the power to order a new stay makes clear that it was aware of this possibility. Hence, even the Court's power to issue writs of mandamus to protect the integrity of its prior judgments from inferior courts' subterfuge cannot provide the legal foundation for an injunction of the breadth and scope of the injunction levied here. ${ }^{130}$

Given the lack of statutory support for the Court's action, it is tempting to invoke the almost mystical nonstatutory "supervisory power," which "allows the [Supreme] Court to intervene to protect the integrity of the federal system." ${ }^{131}$ While the Court has resolutely avoided delineating the precise scope of this nebulous power, the Court's final stay order in this case cannot persuasively rest on this foundation.

All Article III courts are imbued with powers "governed not by rule or statute but by the control necessarily vested in courts to manage their own affairs so as to achieve the orderly and expeditious disposition of cases."132 Supreme Court cases discussing the scope of the supervisory power arise in two different contexts. First, the Supreme Court, like all inferior courts, may invoke the supervisory power to manage proceedings pending before it. Second, the Supreme Court may invoke its supervisory power to review the propriety of a lower court's exercise of its own supervisory power over its own proceedings, just as the Supreme Court may review the merits of a lower court's interpretion and application of statutory and constitutional rules. The Supreme Court, however, has never held that by virtue of its position atop the judicial hierarchy, it enjoys a unique power to supervise the conduct of inferior federal courts beyond this traditional sense of reviewing the soundness of a lower court's exercise of the power to manage its own proceedings. ${ }^{133}$

129. See supra at text accompanying notes 111-13.

130. Perhaps the Court felt that any new claim surfacing at this late date would lack merit, and therefore its broad injunction most likely would not frustrate Harris' legal rights. This assessment, even if accurate, is beside the point. The Court should not rashly issue rulings beyond its power regardless of whether or not tangible injury is likely to result.

131. Frazier v. Heebe, 482 U.S. 641, 648 n.7 (1987); see also McNabb v. United States, 318 U.S. 332 , 341 (1943) (Supreme Court has "supervisory authority over the administration of criminal justice in the federal courts").

132. Chambers v. NASCO, Inc., 111 S. Ct. 2123, 2132 (1991) (citation omitted). For example, federal courts enjoy nonstatutory power to control admission to their bar and discipline attomeys appearing before them, Ex parte Burr, 22 U.S. (9 Wheat.) 529 (1824); vacate judgments procured through fraud, Hazel-Atlas Glass Co. v. Hartford-Empire Co., 322 U.S. 238 (1944); bar disruptive parties from the courtroom, Ilinois v. Allen, 397 U.S. 337 (1970); or dismiss sua sponte suits for failure to prosecute, Link v. Wabash R.R. Co., 370 U.S. 626 (1962).

133. See Bank of Nova Scotia v. United States, 487 U.S. 250, 264 (1988) (Scalia, J., concurring) ("[E]very United States court has an inherent supervisory authority over the proceedings conducted before it.... [W] have authority to review lower courts' exercise of this supervisory authority, insofar as it affects the judgments brought before us, though I do not see the basis for any direct authority to supervise lower 
Even were the Court to assume such a managerial role, it could not persuasively claim the power to supersede congressional decisions about the proper powers of lower courts. Indeed, the Court has repeatedly recognized this limitation: " $[\mathrm{I}] \mathrm{t}$ is well established that " $[\mathrm{e}]$ ven a sensible and efficient use of the supervisory power ... is invalid if it conflicts with constitutional or statutory provisions." 134 As described earlier, lower courts enjoy both explicit and implicit statutory authority in certain circumstances to stay executions and other judgments in order to protect their ability to decide cases within their jurisdiction. ${ }^{135}$ The Supreme Court's decision to enjoin prospectively the federal judiciary from exercising statutorily-granted powers on behalf of Harris thus stretches far beyond interstitial rulemaking into a de facto nullification of congressional directives. ${ }^{136}$

Finally, even were the Court to possess the power in the abstract to suspend the operation of federal statutes, such an extraordinary assertion of managerial power would seem justifiable only if necessary to control outright "judicial usurpation of power"137 by inferior court judges who contravene established legal principles. As explained above, Judge Pregerson's stay order cannot fairly be characterized in such terms. Furthermore, even were such a characterization appropriate, the scope of the Court's prospective injunction remains indefensible. ${ }^{138}$

courts.").

134. Bank of Nova Scotia, 487 U.S. at 254 (quoting Thomas v. Aln, 474 U.S. 140, 148 (1985)); see also Chambers, $111 \mathrm{~S}$. Ct. at 2134 ("It is true that the exercise of the inherent power of lower federal courts can be limited by statute and rule ...."); id. at 2141 (Scalia, J., dissenting) ("Congress may prescribe the means by which the courts may protect the integrity of their proceedings.").

135. See supra notes $111-13$ and accompanying text.

136. At most, the Court possesses the inherent power to dictate lower courts' exercise of their statutory authority only when necessary to protect the Supreme Court's ability to exercise its own jurisdiction. As explained earlier, the Court's injunction against further stays cannot fairly be described as protecting its own ability to entertain Harris' claim. See supra text accompanying notes 115-19.

137. Will v. United States, 389 U.S. 90, 95 (1970).

138. Perhaps the closest the Supreme Court has ever come to wielding such a heavy club over inferior federal courts was during the aftermath of Brown v. Board of Educ., 347 U.S. 483 (1954), when the Court periodically confronted fierce resistance by some federal judges to the implementation of desegregation orders in the South. In Meredith v. Fair, $83 \mathrm{~S}$. Ct. 10 (1962), the United States Court of Appeals for the Fifth Circuit had issued an injunction requiring the University of Mississippi to admit a black applicant. Judge Cameron of that court, however, issued four stays purportedly releasing the University of this obligation pending action by the Supreme Court on a petition for writ of certiorari. On motion by the University applicant, Justice Black issued an in-chambers opinion on behalf of the Court directing that all the stays issued by Judge Cameron be vacated and enjoining respondents from taking any steps to prevent the enforcement of the Court of Appeals' judgment while final action by the Supreme Court was pending.

While the Fair prospective injunction represents a sweeping exercise of power to control a recalcitrant judge, it falls short of providing precedential support for the injunction issued in Harris. First, Judge Cameron's defiant stays were intended solely to preserve the status quo pending Supreme Court review. The stays in Fair were not designed to protect the jurisdiction of the court of appeals; indeed, that court had already determined that Judge Cameron's stays should be treated as "ineffective and void." Id. at 10 . The injunction against seeking further stays below thus sought merely to effectuate the Supreme Court's desire to allow integration to proceed pending its own final action on the University's petition for certiorari.

Second, the injunction did not purport to preclude litigation of new claims related to the University and its race-based admission policy, though concededly any such new claims likely would be dismissed quickly on res judicata grounds. In stark contrast, the injunction in Harris does far more than seek to 
The search for a legal foundation that supports the Supreme Court's final order prohibiting further stays of Harris' execution thus ends in vain; neither the All Writs Act nor the supervisory power offers a sound basis for the Court's behavior. ${ }^{139}$ We strongly suspect that the Court did not pause to consider whether it had a legal basis for the order, which was hastily prepared early in the morning after a full night of activity. The Court's final order clearly communicates a commitment not to legal principles, but to the immediate death of Robert Harris.

\section{CONCLUSION}

How did the Ninth Circuit panel and the Supreme Court come to issue such flawed opinions? Starkly put, judges who have grown impatient with repeated delays prior to executions were determined that Robert Harris be executed on schedule. These judges approached the final attempts to stay his execution with

preempt renewed efforts to subvert the prior Court judgment, stating that Harris' challenge to the gas chamber ought not be entertained by the federal courts; rather, it seeks to control lower court behavior over new claims related to Harris' execution but distinct from the gas chamber claim.

Moreover, even were Fair to provide precedential support for the Court's power to issue a sweeping prospective injunction controlling the jurisdictional powers of inferior federal courts, one might fairly question whether the exercise of such power to protect an individual from the blatant denial of core equality rights is analogous to the exercise of a similar power to hasten the termination of an individual's life.

139. The final order cannot be justified as a "lesser" power subsumed within a "greater" power to control lower court behavior through the conventional exercise of certiorari jurisdiction. In theory, the Court could have treated the State's application to vacate the final stay as a petition for certiorari, granted the petition, and assumed jurisdiction over the $\$ 1983$ case. Pending a decision on the merits, this action arguably would have divested all inferior federal courts of their power to act (including the power to grant stays) with respect to the gas chamber claim. But it seems farfetched to suggest that the Court could also sua sponte have invoked a principle of "supplemental jurisdiction" to broaden the scope of its certiorari grant, thereby including any and all legal claims that Harris might raise in subsequently filed actions and divesting all lower federal courts of their power to act with respect to them.

The idea that the Court may in essence grant certiorari in advance over claims not yet filed is more than unprecedented; it also appears to contravene statutory and constitutional limits on the Court's certiorari jurisdiction. The fact that 28 U.S.C. $\$ 1254(1)$ (1988) expressly authorizes the Court to take certiorari jurisdiction after a district court decision but prior to review by a circuit court of appeals implies that the Court may not assume certiorari jurisdiction over a case prior to some district court decision.

Indeed, this statutory scheme services Article III's limitation on the Supreme Court's power to exercise original (as opposed to appellate) jurisdiction. The constitutional requirement that the Court entertain conventional federal claims only in its appellate capacity ensures that such claims are first considered by a court that is closer, both geographically and cognitively, to the parties and the controversy. When crafting its ultimate resolution, the Supreme Court, distanced both by space and seclusion, benefits from the local court's wisdom and insight. By eliminating this benefit, the purported "greater" power of controlling lower court behavior by exercising a prospectively operational certiorari jurisdiction over subsequently filed civil suits relating to Harris' execution would unconstitutionally expand the Court's original jurisdiction. (This defect may technically not apply to habeas petitions, which may be viewed from the outset as a form of appellate review. But the same policy concerns regarding detached adjudication apply, so the Court's order pertaining to subsequently filed habeas claims would still appear to run afoul of the spirit of Article III's limits on original jurisdiction.)

We add that even if the Court could actually have achieved its desired result through the exercise of certiorari jurisdiction, it should have done so directly and candidly. Mere inclusion of a blanket prohibition in a stay order allowed the Court to act aggressively without the self-discipline and public accountability that likely would have been engendered had the Court officially granted certiorari and assumed direct responsibility for the case. 
disdain and had no desire to consider (nor to let other courts consider) the merits of his claim. In their effort to ensure that death not be delayed, their legal opinions were quickly prepared and poorly reasoned.

Such haste in judicial decisionmaking is rarely desirable, and certainly less so when the consequence is an execution. Why was it so imperative that the State execute Harris on April 21: What was the real harm in delaying Harris' death until a new execution date could be set in another month? Judge Noonan, in his dissenting opinion to the Ninth Circuit panel decision, explained:

It is clear that in this case and in the related proceedings involving Robert Harris a sense of urgency has pervaded the litigation. Such urgency is understandable on the part of counsel for the state who are charged with making sure that Harris is executed; it is evident what they believe their primary duty to be. Such urgency, however, cannot be the priority of this court, whose task is to enforce the Constitution of the United States while observing the rules by which the federal judicial system functions and the rules by which we as a court are organized. ${ }^{140}$

The reality is that the State is only minimally inconvenienced by an additional delay. Where a federal district court justifies a delay in execution by concluding that death in the gas chamber is of sufficiently dubious constitutionality to warrant full consideration of the merits, it is particularly unseemly to deem the State's desire for execution on the designated date as more important than resolution of the constitutional claim.

We understand the Court's growing frustration with last-minute appeals that are the norm in capital cases. The Court has limited such requests by imposing more stringent procedural requirements on successive habeas corpus petitions. ${ }^{141}$ While we disapprove of this particular measure, we recognize that more conservative jurists and citizens support this and other measures to ensure that the State's interest in implementing its sanctions is not stymied by a flurry of frivolous last-minute claims. We firmly believe, however, that persons across the ideological spectrum should be troubled that the Court's desire to expedite the process of death-perhaps rooted in legitimate concerns about abuse in specific cases-has now accrued a life of its own. Rather than scrutinizing a last-minute appeal carefully, the Court now apparently assumes without evaluation that any such filing is frivolous and in bad faith. In this case, the poorly reasoned opinions of the Ninth Circuit panel and Supreme Court reveal this knee-jerk tendency. The tragedy of Robert Alton Harris' execution is that judges, sworn to uphold the law, disregarded it to satisfy the State's desire to

140. Gomez v. Fierro, No. 92-70237, 1992 U.S. App. LEXIS 7931, at**9-10 (9th Cir. Apr. 20, 1992) (Noonan, J., dissenting).

141. McCleskey v. Zant, $111 \mathrm{~S}$. Ct. 1454 (1991) (no repeat habeas petitions unless petitioner can demonstrate cause and prejudice for not raising claim in earlier petition). 
execute Harris according to schedule. Justice requires more than ensuring that the trains run on time. 